\title{
Pemberdayaan anggota PKK Desa Pandau Jaya dalam pembuatan pakan jamu fermentasi untuk meningkatkan kesehatan ikan budidaya
}

\author{
Henni Syawal (D)*, Nuraini, Saberina Hasibuan (D), \& Syafriadiman (D) \\ Universitas Riau \\ * henni.syawal@lecturer.unri.ac.id
}

\begin{abstract}
Abstrak. Desa Pandau Jaya termasuk salah satu desa di Kecamatan Siak Hulu Kabupaten Kampar. Kegiatan pengabdian dilaksanakan bersamaan dengan kegiatan mahasiswa kukerta terintegrasi UNRI tahun 2019 dan bekerjasama dengan mitra (CV Bang Lele Indonesia) dalam kegiatan pengabdian,. Tujuan kegiatan ini adalah untuk memberdayakan anggota PKK dalam pembuatan jamu fermentasi, hasilnya nanti dijual kepada CV Bang Lele Indonesia untuk digunakan dalam pemberian pakan kepada ikan-ikan budidaya sehingga dapat meningkatkan pertumbuhan, kesehatan dan tahan terhadap penyakit. Metode yang dilakukan adalah, pertama metode ceramah dan diskusi, yakni penyampaian materi yang berhubungan dengan kegiatan pembuatan jamu fermentasi, kemudian dilanjutkan dengan praktek pembuatan jamu, penebaran benih ikan, dan cara pemberian pakan jamu kepada ikan yang telah dipelihara oleh mitra. Berdasarkan hasil kegiatan pengabdian ini ada dua orang peserta yang telah berhasil melakukan pembuatan jamu fermentasi dan langsung diaplikasikan dalam kegiatan budidaya, sedangkan yang satu orang lagi hanya memproduksi jamu fermentasi dan dijual kepada CV Bang Lele Indonesia. Pengamatan terhadap pertumbuhan dan kelulushidupan ikan diamati selama dua bulan. Jenis ikan yang dipelihara adalah ikan lele dan nila. Hasil pengamatan terlihat ikan-ikan yang dibudidayakan mengalami pertumbuhan yang cepat, yakni selama 60 hari pemeliharaan terjadi penambahan panjang rata-rata $10 \mathrm{~cm}$ dan berat $50 \mathrm{~g}$ untuk ikan nila, sedangkan pada lele. $12 \mathrm{~cm}$ dan berat $75 \mathrm{~g}$.
\end{abstract}

Kata kunci: jamu fermentasi; pertumbuhan; CV bang lele Indonesia

\begin{abstract}
Pandau Jaya Village is one of the villages in Siak Hulu Subdistrict, Kampar Regency. The dedication activity was carried out in conjunction with the integrated student activities of UNRI in 2019 and in collaboration with partners (CV Bang Lele Indonesia) in the service activities. The purpose of this activity is to empower PKK members in making fermented herbal medicine, the results will be sold to CV Bang Lele Indonesia for use in feeding fish to aquaculture so as to enhance growth, health and disease resistance. The method used is, first the lecture and discussion method, namely the delivery of material related to the activities of making fermented herbs, then continued with the practice of making herbs, spreading fish seeds, and how to feed herbal medicine to fish that have been maintained by partners. The results of this community service activity, there were two participants who had succeeded in making fermented herbal medicine and immediately applied it in cultivation activities, while the other one only produced fermented herbal medicine and was sold to CV Bang Lele Indonesia. Observation of growth and survival. fish were observed for two months. The types of fish that are kept are catfish and tilapia. The results of the observations showed that the cultivated fish experienced rapid growth, that is, during the 60 days of maintenance there was an increase in the average length of $10 \mathrm{~cm}$ and a weight of $50 \mathrm{~g}$ for tilapia, whereas in catfish $12 \mathrm{~cm}$ and weights $75 \mathrm{~g}$.
\end{abstract}

Keywords: herbal medicine; fermentation; growth; CV bang lele Indonesia

To cite this article: Syawal, H., Nuraini, S. Hasibuan, \& Syafriadiman. 2019. Pemberdayaan anggota PKK Desa

Pandau Jaya dalam pembuatan pakan jamu fermentasi untuk meningkatkan kesehatan ikan budidaya. Unri

Conference Series: Community Engagement 1: 623-627 https://doi.org/10.31258/unricsce.1.623-627

(C) 2019 Authors

Peer-review under responsibility of the organizing committee of Seminar Nasional Pemberdayaan Masyarakat 2019 


\section{PENDAHULUAN}

Budidaya perikanan adalah suatu kegiatan pemeliharaan ikan yang dilakukan secara terkontrol, untuk mendapatkan keuntungan dengan memperhatikan lingkungan. Tingginya kesadaran masyarakat akan pentingnya hidup sehat dan menjadikan anak-anak yang cerdas, mengingat ikan sebagai sumber protein yang sangat dibutuhkan tubuh untuk memperbaiki sel-sel yang rusak dan kandungan asam amino ikan serta adanya kandungan omega 3 dan 6 yang diyakini dapat meningkatkan kecerdasan anak. Berdasarkan hal ini, maka animo masyarakat untuk melakukan kegiatan budidaya ikan baik di pedesaan maupun di perkotaan meningkat jumlahnya.

Kegiatan budidaya ikan yang dilakukan di perkotaan saat ini telah memanfaatkan teknologi tepat guna, yakni seperti budidaya ikan pada kolam terpal berbentuk persegi dan bulat, serta dalam drum, selain itu kegiatan ini ada juga yang dilakukan dengan sistem bioflok atau akuaponik. Usaha ini sangat bermanfaat karena selain dapat memenuhi kebutuhan gizi keluarga juga dapat dijadikan sebagai usaha pokok atau sampingan, dan bahkan bisa dijadikan sebagai wisata keluarga. Dengan adanya kegiatan ini maka dapat meningkatkan kesejahteraan dan kebahagian keluarga.

Pakan jamu adalah pakan pellet yang diberi jamu (herbal), adapun komposisi jamu tersebut antara lain mengandung kunyit, kencur, temulawak. Ketiga bahan ini mengandung kurkumin yang bermanfaat dapat meningkatkan nafsu makan ikan, meningkatkan daya cerna ikan, meningkatkan kesehatan ikan, dan menghemat penggunaan pakan pellet, sehingga nilai efisiensi pakan tinggi.

Pemberian pakan dengan penambahan ekstrak kurkumin memberikan hasil yang bervariasi pada pertumbuhan bobot mutlak ikan jambal siam. Kurkumin dapat berasal dari kunyit, temulawak, dan kencur. Kunyit adalah bahasa umum untuk Indonesia, walaupun disetiap daerah ada perbedaan namanya. Kunyit disebut juga kurkuma atau turmerik (India). Kurkuminoid merupakan zat pemberi warna kuning pada kunyit. Rimpang tanaman kunyit bermanfaat sebagai anti inflamasi, anti oksidan, anti mikroba, dan dapat meningkatkan kerja organ pencernaan (1).

Meningkatnya pertumbuhan didukung dengan kesehatan yang baik pada ikan dan akan meningkatkan efisiensi penyerapan zat makanan untuk memenuhi kebutuhan hidup dan produksi yang ditunjukkan dengan pertambahan bobot (2). Hal ini disebabkan karena ekstrak kurkumin selain bersifat antibakteri dan antiflamasi juga dapat meningkatkan nafsu makan ikan sehingga penyerapan zat nutrisi menjadi lebih baik dan dapat memicu pertumbuhan (3).

Tumbuhan yang dapat digunakan sebagai suplemen diantaranya, kunyit, temulawak, dan kencur. Kunyit mengandung beberapa senyawa diantaranya, minyak atsiri, turmeron, zingiberen, protein, karbohidrat, lemak, vitamin C, zat besi, fosfor, magnesium, alkaloid, flavonoid, tannin, resin dan kurkumin. Manfaat kunyit adalah untuk merangsang gerakan usus dalam mencerna pakan lebih optimal (4). Sedangkan kencur memiliki aktivitas inflamasi, antifungi, dan antibakteri yang berasal dari senyawa seperti, minyak atsiri, polifenol, kuinon, sineol, tannin, saponin, dan flavonoid (5). Selanjutnya temulawak juga mengandung protein, pati, minyak atsiri, alkaloid, kuinon, dan flavonoid berfungsi untuk meningkatkan daya tahan tubuh dan meningkatkan nafsu makan ikan (6). Pemberian suplemen herbal dengan proses fermentasi dalam pakan mampu merangsang nafsu makan ikan, meningkatkan kekebalan ikan terhadap penyakit dan mengurangi tingkat stress ikan terhadap perubahan lingkungan (7). Proses fermentasi mampu mengurai senyawa kompleks menjadi sederhana yang tidak mudah dicerna. Melalui fermentasi, bahan pangan akan mengalami perubahan fisik dan kimia yang menguntungkan seperti terbentuknya flavor dan aroma yang disukai. Adanya zat aktif yang terkandung dalam suplemen herbal dapat meningkatkan sistem pertahanan tubuh, pertumbuhan dan kesehatan ikan (8).

Pemberian pakan jamu fermentasi pada ikan patin yang dipelihara dalam keramba jarring apung yang ditancapkan di kolam, menghasilkan pertumbuhan yang cepat, yakni pertambahan panjang sebesar 109\% (panjang awal $11 \mathrm{~cm}$ dan akhir 23cm) sedangkan berat (awal 17,5 g dan akhir 112,5g) (9). Berdasarkan penjelasan di atas maka kami tertarik untuk membuat jamu fermentasi yang bahan bakunya mudah didapatkan dan memiliki nilai guna yang tinggi terutama dalam meningkatkan pertumbuhan ikan-ikan budidaya.

Target yang ingin dicapai dari kegiatan ini adalah dapat membantu petani ikan dan masyarakat Desa Pandau Jaya dalam mengatasi harga pakan yang mahal dengan membuka lapangan pekerjaan baru, yakni memproduksi jamu fermentasi. Dengan adanya kegiatan ini maka masalah harga pakan yang mahal dapat teratasi dan sekaligus bisa menambah pendapatan keluarga. 


\section{METODE PENERAPAN}

Kegiatan pengabdian ini dilakukan di RW05 Dusun 05 Desa Pandau Jaya Kecamatan Siak Hulu, Kabupaten Kampar. Alasan melibatkan ibu-ibu PKK sebagai peserta pelatihan adalah mengingat ibu-ibu ini memiliki banyak waktu untuk dapat melakukan usaha pembuatan jamu fermentasi, selain itu juga dapat menjadikan kegiatan ini sebagai mata pencaharian tambahan bagi ibu-ibu atau masyarakat di Desa Pandau Jaya. Metode yang digunakan adalah metode ceramah dan praktek, Sebelum dilakukan ceramah dan diskusi terlebih dahulu dilakukan Tes untuk melihat sejauhmana pengetahuan peserta terhadap materi yang akan diberikan, kemudian diakhir kegiatan juga dilakukan Postes, tujuannya untuk melihat peningkatan pengetahuan peserta. Metode ceramah, yakni menyampaikan teori yang berhubungan dengan kegiatan budidaya dan manfaat dari pakan jamu fermentasi pada ikan budidaya dengan bantuan alat presentasi, yakni Infocus dan alat tulis serta handout. Sedangkan kegiatan praktek dilakukan secara bersama-sama oleh pemateri dan para peserta.

\section{Prosedur pembuatan jamu fermentasi}

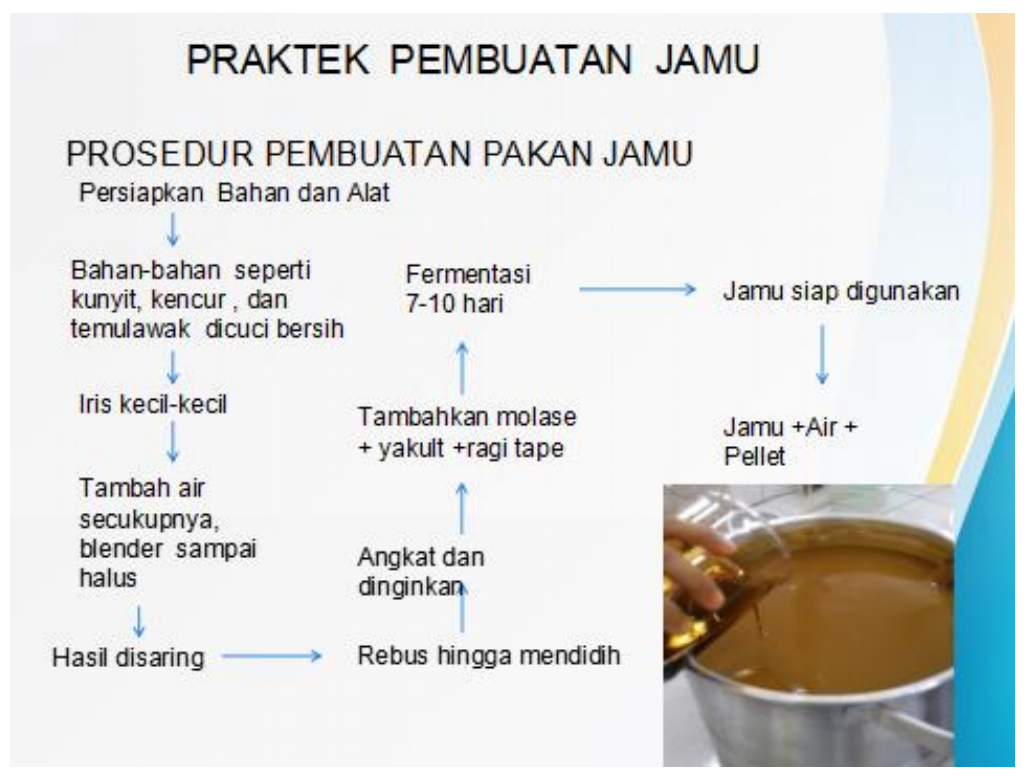

Jamu yang ditambahkan ke pakan adalah sebanyak 100mL/ kg pakan, jamu sebelum dicampur dengan pakan terlebih dahulu dicampur dengan air bersih sebanyak $500 \mathrm{~mL}$. Setelah jamu tercampur rata baru dicampurkan ke pakan, lalu aduk sampai rata dan dibiarkan selama 10 menit agar pakan menjadi lembut baru diberikan ke ikan.

\section{Persiapan kolam dan pemeliharaan ikan}

Bersamaan dengan persiapan pembuatan jamu, juga dipersiapkan dan dibersihkan dua unit kolam untuk pemeliharaan ikan lele dan nila, kolam yang digunakan adalah kolam terpal berbentuk bundar dengan diameter $2 \mathrm{~m}$ kemudian diisi air dan diberi aerasi. Selanjutnya satu unit kolam diisi dengan benih ikan nila dan satu lagi lele, masing-masing kolam diisi benih ikan ukuran 5-7cm dengan padat tebar 1000 ekor. Ikan diberi pakan 3 kali sehari sebanyak 10\% dari berat populasi. Pemeliharaan dilakukan selama dua bulan. Untuk melihat keberhasilan pertumbuhan ikan selama pemeliharaan maka dilakukan pengukuran terhadap panjang dan bobot ikan yang dipelihara, dan dihitung Efisiensi Pakan serta FCR.

\section{HASIL DAN KETERCAPAIAN SASARAN}

Kegiatan pelatihan dan pengabdian kepada masyarakat yang dilaksanakan di RW05/Dusun 05 Desa Pandau Jaya dengan jumlah peserta sebanyak 40 orang, yang terdiri dari 20 orang Ibu-ibu PKK, 10 orang peserta magang di tempat mitra pengabdian (CV. Bang Lele Indonesia), sisanya mahasiswa KKN terintegrasi tahun 2019. 

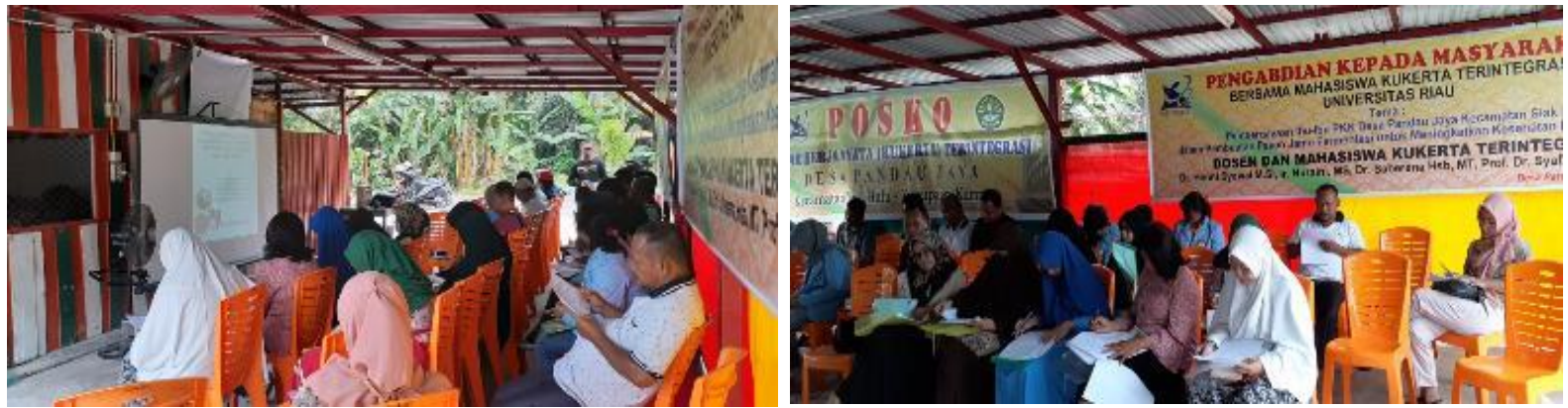

Gambar 1. Peserta dengan serius menjawab soal tes di awal dan akhir

Hasil penilaian terhadap pertanyaan yang diberikan sebelum penyampaian materi maupun setelah, terlihat disini ada peningkatan pemahaman peserta terhadap materi yang diberikan. Dari 10 pertanyaan yang berkaitan dengan kegiatan diberikan sebelum mengikuti pelatihan maka peserta hanya mampu menjawab 30-50\%. Sedangkan diakhir kegiatan pertanyaan yang sama dites lagi, maka peserta mampu men-jawab 75-90\%. Artinya para peserta dapat memahami materi yang disampaikan oleh Tim. Berikut ditampilkan foto kegiatan pembuatan jamu fermentasi dan kunjungan ke kolam terpal budidaya ikan lele dan nila yang dijadikan kolam praktek.
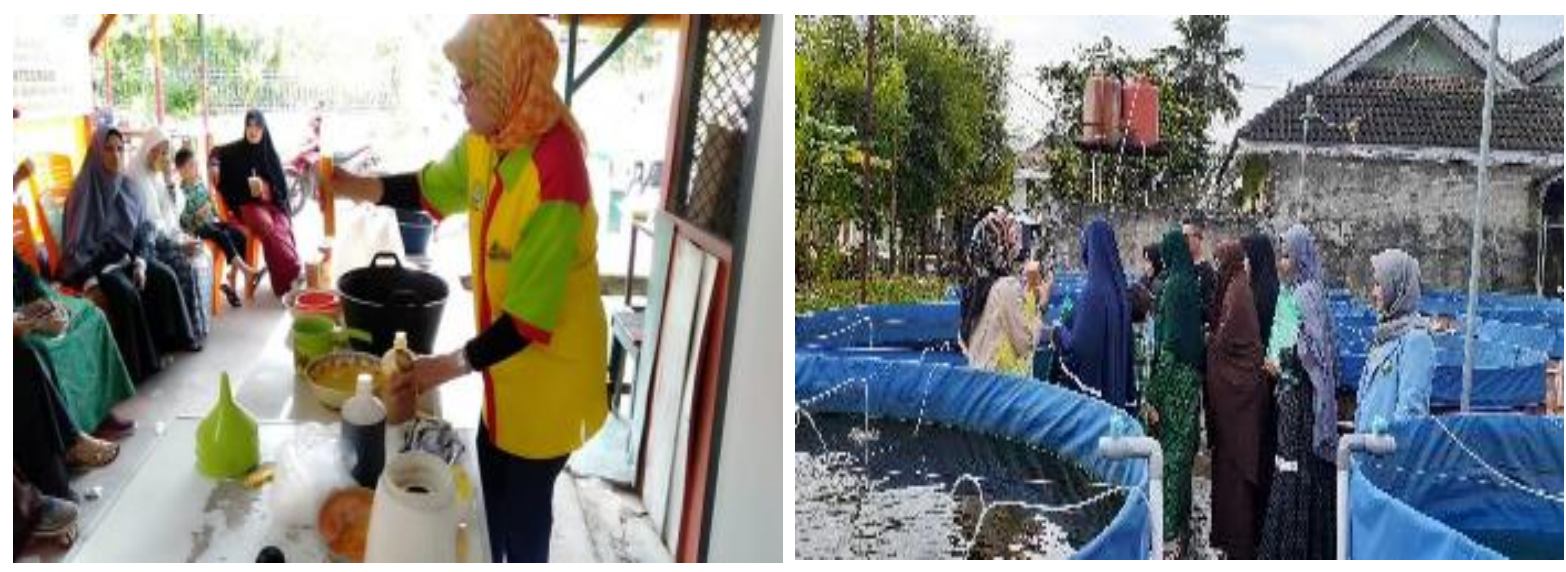

Gambar 2. Pembuatan jamu fermentasi dan kolam terpal
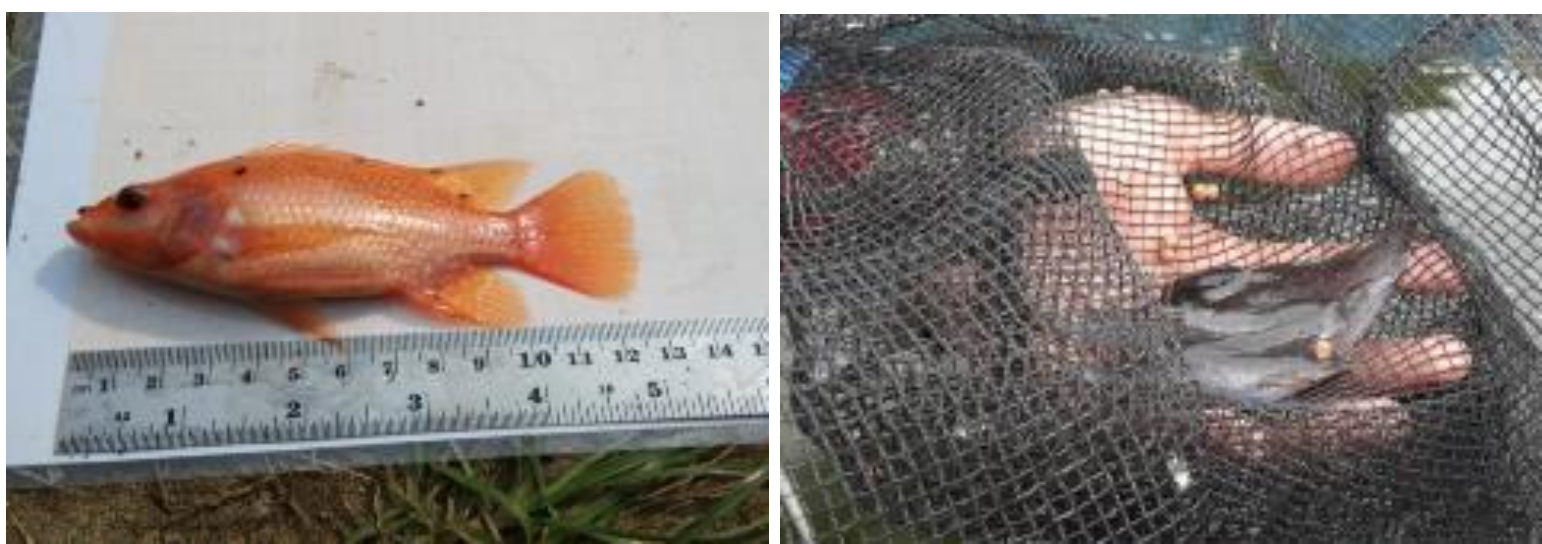

Gambar 3. Ikan Nila dan Lele yang dipelihara dalam kolam terpal dan diberi pakan pellet+jamu fermentasi. Berat ikan nila pada saat 1 bulan pemeliharaan $(40 \mathrm{~g})$ dan lele ( $30 \mathrm{~g})$

Berdasarkan hasil pengamatan maka ikan nila yang dipelihara dalam kolam terpal dan diberi pakan jamu fermentasi lebih cepat pertumbuhannya dibandingkan dengan ikan lele yang juga dipelihara dalam kolam terpal yang sama diberi pakan jamu fermentasi. Jenis pakan yang diberikan adalah pakan dengan kadar protein rendah, yakni $16 \%$. Pakan yang kadar protein rendah ini setelah ditambahkan jumu permentasi, kemudian dicampur secara merata dan dibiarkan selama 10-15 menit agar jamu dapat meresap dengan baik sehingga 
dapat meningkatkan kadar protein hingga 1,2\%. Adanya perbedaan pertumbuhan ikan nila dengan lele diduga karena nila bersifat herbivora sedangkan lele bersifat karnivora. Artinya ikan yang carnivore dalam masa pertumbuhannya membutuhkan protein yang tinggi, sedangkan ikan nila bersifat herbivore dengan kadar protein yang rendah sudah cukup. Hal ini sesuai dengan pendapat (9): bahwa ikan patin yang juga bersifat carnivore dipelihara selama 45 hari dalam keramba jarring apung yang ditancapkan pada kolam, dan diberi pakan dengan kadar protein 35\% dapat mencapai bobot sebesar $125 \mathrm{~g}$.

\section{KESIMPULAN}

Berdasarkan hasil pengamatan selama kegiatan pengabdian kepada masyarakat di Desa Pandau Jaya, maka ibu-ibu PKK sudah ada yang melakukan pembuatan jamu fermentasi untuk usaha budidaya ikan sendiri, selain itu juga ada sebagai produsen jamu fermentasi yang kemudian hasilnya dijual kepada mitra. Mitra yang menggunakan jamu fermentasi merasakan sekali manfaatnya, karena dapat meningkatkan kadar protein pakan hingga 1,2\%, nafsu makan ikan, pertumbuhan ikan, hemat penggunaan pakan.

\section{UCAPAN TERIMA KASIH}

Ucapan terima kasih kami sampaikan kepada Ketua LPPM beserta jajarannya yang telah mempercayai kami untuk melaksanakan kegiatan pengabdian kepada masyarakat dengan sumber dana DIPA Universitas Riau tahun anggaran 2019 (No. Kontrak. 451/UN.19.5.1.3/PT.01.03/2019).

\section{DAFTAR PUSTAKA}

Balittro, 2008. Budidaya Tanaman Kunyit. http://www.balittro.go.id/incles/kunyit.pdf tanggal akses: 5 Maret 2016.

Gupta, A., S. Mahajan, \& R. Sharma. 2015. Evaluation of Antimicrobial Activity of Curcuma Longa Rhizome Extract Againts Sthapylococcus aureus. Biotechnology Reports, 6, 51-55

Hasanah, A.N., F. Nazaruddin, E. Febrina, \& A. Zuhrotun. 2011. Analisis Kandungan Minyak Atsiri dan Uji Aktivitas Antiinflamasi Ekstrak Rimpang Kencur (Kaempferia galanga L.). Jurnal Matematika dan Sains, 16(3), 14 -152.

Koesdarto, S. 2001. Model Pengendalian Siklus Infeksi Toxocariasis dengan Fraksinasi Minyak Atsiri Rimpang Temulawak (Curcuma xanthorrhiza Roxb) di Pulau Madura. Jurnal Penelitian Media Eksakta, 2(1), 17-21.

Mutrikah., H. Santoso, \& A. Sauqi. 2018. Profil Bioaktif pada Tanaman Temulawak (Curcuma xanthorriza Roxb) dan Beluntas (Pluchea indica Less). Bioscience Tropic, 4(1), 15-21.

Puspitasari, D. 2017. Efektivitas Suplemen Herbal Terhadap Pertumbuhan dan Kelulushidupan Benih Ikan lele (Clarias gariepinus). Jurnal ilman 5(1), 53-59.

Samsundari, S. 2006. Pengujian Ekstrak Temulawak dan Kunyit Terhadap Resistensi Bakteri Aeromonas hydrophila yang Menyerang Ikan Mas (Cyprinus carpio). Gamma, 2(1), 71-83.

Syawal, H., N.A. Pamukas, \& N. Asiah. 2017. Pakan Jamu untuk Ikan Budidaya. Buku Teknologi Tepat Guna. Pekanbaru: Universitas Riau Press. $16 \mathrm{hlm}$

Syawal, H., M. Riauwaty, Nuraini, \& S. Hasibuan. 2018. Pemanfaatan Pakan Herbal (Jamu) untuk Meningkatkan Produksi Ikan Budidaya. Buku Teknologi Tepat Guna. Pekanbaru: Universitas Riau Press. 14 hlm. 